\title{
Research on Current Situation of Overseas Vietnamese Students and Its Policy Improvement
}

\author{
Anh Thu Vo \\ School of Humanities and Law \\ Northeastern University \\ Shenyang, China \\ Ho Chi Minh City University of Physical Education and Sport \\ Ho Chi Minh, Vietnam
}

\author{
Wanbing Shi \\ School of Humanity and Law \\ Northeastern University \\ Shenyang, China
}

\begin{abstract}
It is of great importance to explore the current situation of overseas Vietnamese students and policy improvement, in order to improve the management level of overseas Vietnamese students. Research methods like statistical method, inductive method and policy analysis method are applied to conclude the current situation of overseas Vietnamese students, analyze factors influencing the ambition of them and predicaments in studying abroad, and then propose adjusting study-abroad policy of Vietnamese government. It encourages overseas students to study hard and mobilizes them to return home to work, in order to improve the management level of overseas Vietnamese students and promote the development of study-abroad career in Vietnam.
\end{abstract}

Keywords-Vietnam; study abroad; students' situation; influence factors; predicaments; policy improvement

\section{INTRODUCTION}

Unprecedented seminars about education issues are held in Vietnam. Education frequently appears in periodicals and magazines. It seems overseas studying becomes the headline news. The Vietnamese people want to reinvent themselves through the revolution in education. It is the development guideline of the Vietnamese government and the wish of the Vietnamese people. Education for studying abroad is a root in society.

Vietnam formally entered the World Trade Organization (WTO) in January 2007. The Vietnamese government makes continuous efforts to establish a steady market economic system with sustainable development. The economic market transforms greatly and brings vitality and challenges for the society in Vietnam. In the past ten years, the pressure of educational reform and globalization of education has become the problem that rack mind of the Vietnamese government, the Ministry of Education, the education management organization, leaders of educational business and experts who guide in formulating educational policies. In order to integrate Vietnam in the world development and let it develop in global development, the sustainable development of market economic system in Vietnam requires educational departments to ensure the global labor force and build a train talent team that reaches

Fund Project: National Fund Pedagogy Project of Social Sciences "The Evaluation System Research of Universities' Scientific Research Performance of Humanistic and Social Science" (Project No.: BFA150043). the international standard and becomes the pioneer in the development of Vietnam. In recent years, colleges in Vietnam have implemented policies to reach the goal of internationalization and have obtained results but fail to achieve obvious success. According to the data statistics of the Ministry of Education in Vietnam, from 2008 to the beginning of 2017, the number of overseas students in Vietnam grows from 60,000 to 130,000 with the average annual growth rate of 11.67 percent. [1] It proves the internationalization of educational objectives of the Vietnamese government and aspirations of students to study abroad. The most important method to realize soaring increase is the scheme of investing in studying abroad to enjoy international high quality educational environment.

\section{STATISTICS OF CURRENT SitUATION OF OVERSEAS STUDENTS FROM VIETNAM}

\section{A. Growing Rate of Overseas Students}

According to the data statistics from 2000 to 2007 of the Ministry of Education in Vietnam, the destination countries of many Vietnamese in studying abroad include developed countries like America, Britain, Australia, France, Germany and Japan. There were 39,700 people studying abroad in 2007, 2,684 of which accepted educational appropriation from the country and the rest went to study abroad at their own expense. [2] There is a training project for graduate students to study abroad related to educational appropriation of the Vietnamese government (322 Project for short). In the first period, students have been sent to over thirty countries to study with the top three of 496 in Russia, 357 in Australia and 334 in America. The science and technology industry accounts for the highest of 41.49 percent, the science of 14.55 percent and the business management of 14.42 percent. From 2006 to 2014, the projected expenditure in the second period of 322 Project is 260 billion Vietnamese dongs (about 118.2 million US dollars). From 2008 to 2010, the Ministry of Education in Vietnam annually allocates 400 scholarships. About fifty percent of appropriation is for advanced countries like America, Canada, Britain, Germany, France, Netherlands, Russia, Australia, New Zealand, Japan and Korea to train doctorate. The prior specialties of training include information technology, biotechnology, material technology, nanotechnology and high 
technology. Ruan Chunwang, the former director of the Foreign Training Bureau in the Ministry of Education and Training in Vietnam addresses, in 2008, in order to provide high quality human resource for the national government, the Ministry of Education has approved twenty-five students who participate in the Olympic Games to study abroad. Students who win gold award in the Olympic Games will be sent to first-class advanced countries like America and Britain to study. Students ranking the top 30 in the domestic university examination and ranking first in the high school graduation examination will be sent uniformly.
According to the data statistics during 2008 and 2009, the number of overseas students has reached 60,000, more than 4,000 of which adopt educational appropriation of the country and the rest are students who go to study abroad at their own expense. The number of overseas students has reaches more than 100,000 during 2010 and 2011. According to the newest data statistics during 2016 and 2017, the number of overseas students has reached more than 130,000, ninety percent of which go to study abroad at their own expense.

TABLE I. L LIST OF GROWTH IN TOTAL NUMBER OF OVERSEAS STUDENTS IN VIETNAM

\begin{tabular}{|c|l|l|l|l|l|l|}
\hline School year & $2006-2007$ & $2008-2009$ & $2010-2011$ & $2012-2013$ & $2014-2015$ & $2016-2017$ \\
\hline Number of people & 39.700 & 60.000 & 100.000 & 125.000 & 110.000 & 130.000 \\
\hline
\end{tabular}

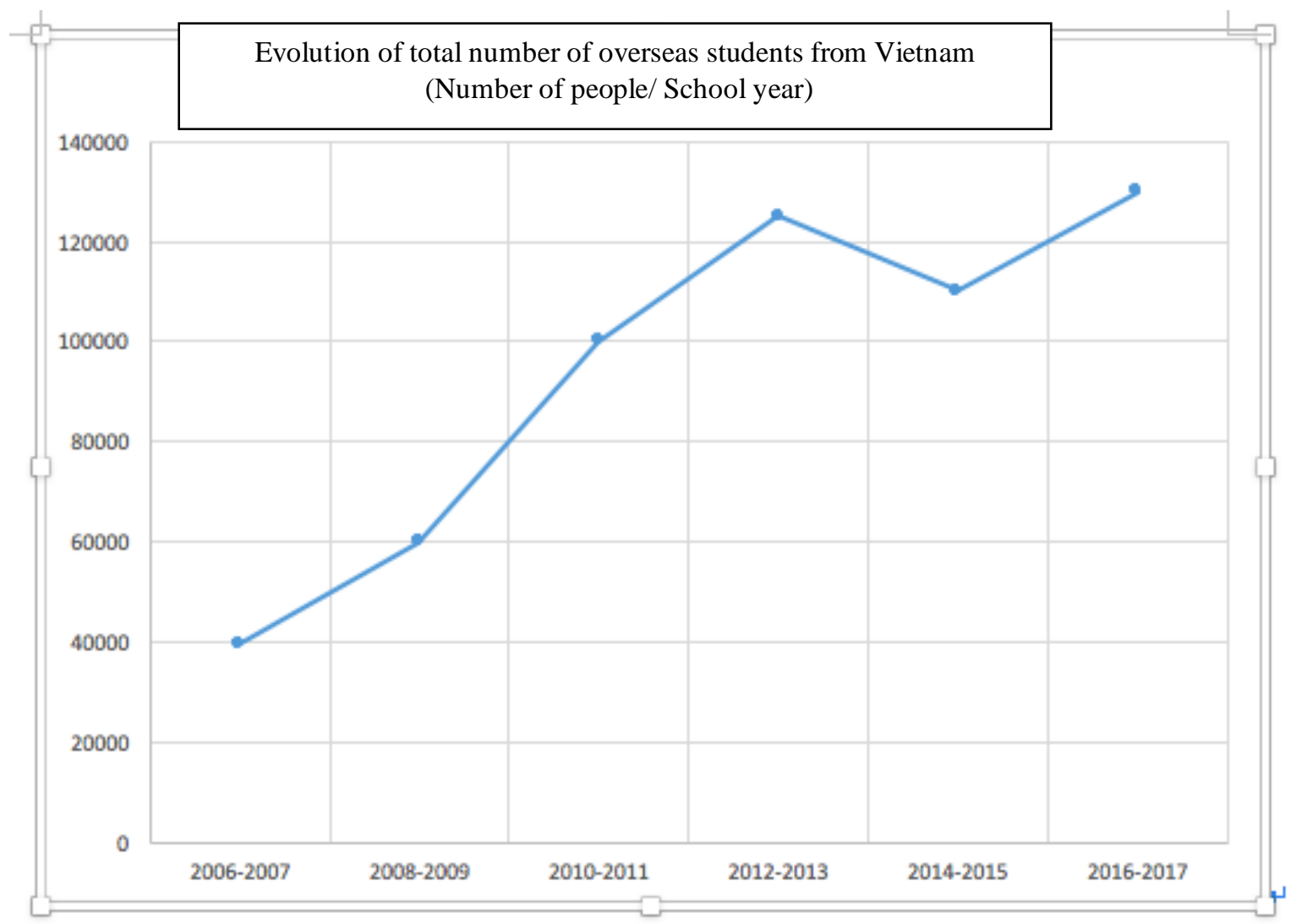

Fig. 1. Growth of number of overseas students from Vietnam. (Data source: the information on annual educational statistics disclosed on the website by the Ministry of Education in Vietnam: http://pbc.moet.gov.vn/?page=9.6)

B. Current Situation of Overseas Students from Vietnam in Typical Countries and the Tendency of Their Selection

The tide of studying abroad in Vietnam sprung up in the late five years in the 1990s. At that time, the Ministry of Education and Vietnamese students valued the educational environment in many countries like America, France, Britain and Russia and gave priority to these countries. In 2000, the study-abroad market of the Ministry of Education in Vietnam grew. Countries like Australia, Germany, Singapore and China are selected by them. Ruan Dengxian, the general manager of the ASCI global study-abroad head office in Hanoi of Vietnam observes, students in Ho Chi Minh City in South Vietnam tend to choose schools in America, Singapore and Australia and students in Hanoi tend to choose schools in China, Britain, Switzerland, America and Australia. First, the strengths of China for overseas students include traditional Chinese medicine and pharmacy and social sciences; the tuition fee and 
living expenses of China are acceptable. Second, the reason why many Vietnamese students choose to study in Switzerland is that the hotel management and the travel industry of it are perfect. Third, the reason why they go to Singapore is that they accept the overseas study expense of this country. The statistical survey proves the expense of studying a master's degree in Singapore is about 300 to 400 million Vietnamese dongs (about 14,000 to 18,000 US dollars).

The data statistics of the Foreign Training Bureau in the Ministry of Education in Vietnam from 2010 to 2011 shows more than 100,000 students study in forty-nine countries. Although there are about 25,000 Vietnamese students studying in Australia, this country has the most Vietnamese students. The number two and the subsequent ranking in the data statistics of Vietnamese students are America of about 14,888, China of about 12,500, Singapore of 7,000, Britain of 6,000, France of 5,540, Russia of 5,000 and Japan of 3,500. Students to study in America have record-breaking growth. Some
American universities even list Vietnamese students in the "potential new market". Hot issues about Vietnamese students become the focus of American educational media. The annual report statistics of Open Doors of the Institute of International Education in 2011 show the growth rate of Vietnamese students reaches fourteen percent ranking eight in the ranking list of going to studying in America from 2010 to 2011, and it ranks twenty in the previous five years. Undergraduates, graduate students and students of other classes and grades and students for professional improvement account for 72.1 percent, 15.2 percent, 9.9 percent and 2.8 percent respectively. [3]

In the recent two years during 2016 and 2017, Vietnamese students study in America, Britain, Australia, Japan and China. Japan has the most Vietnamese students of 38,000. The countries ranking second, third, fourth and fifth are Australia, America, China and Britain with Vietnamese students of $31,000,28,000,13,000$ and 11,000 respectively.

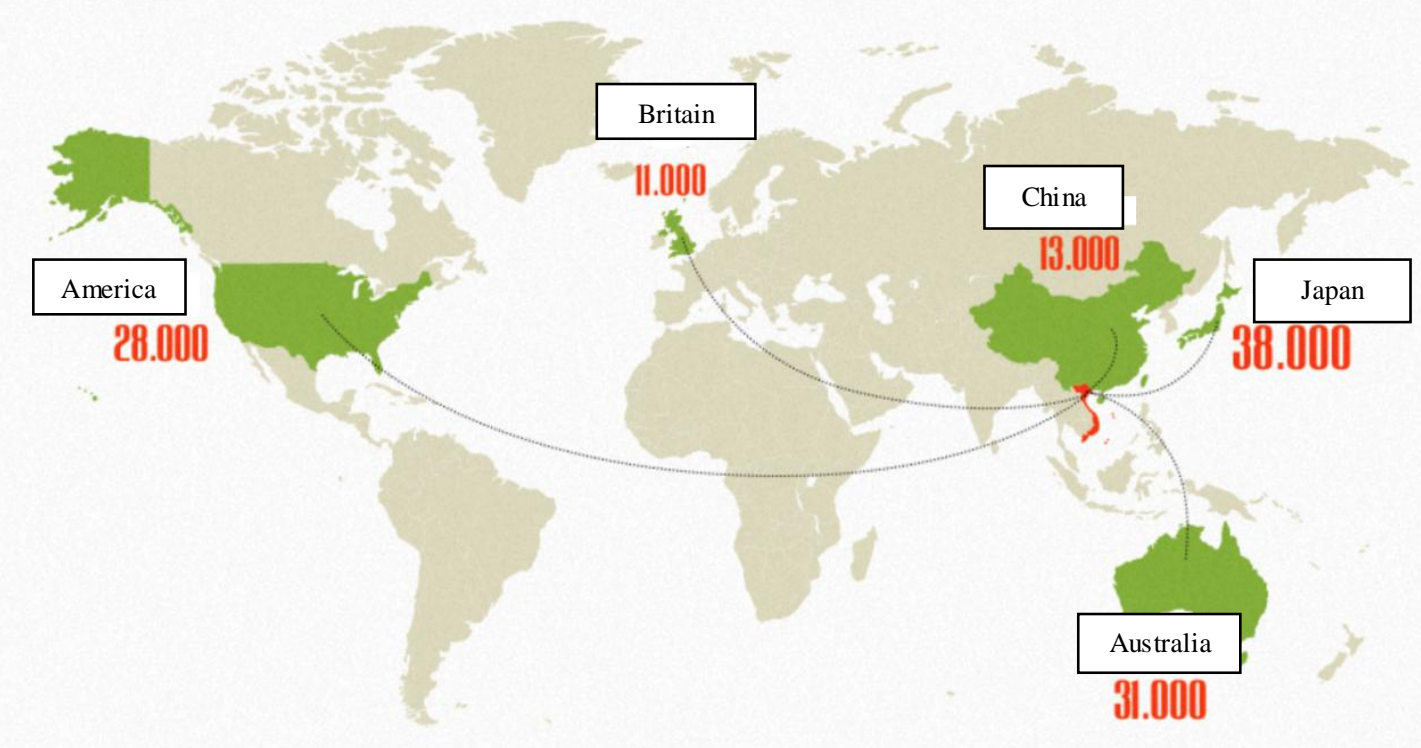

Fig. 2. Distribution of overseas Vietnamese students during 2016 and 2017. (Data source: statistical information of overseas study from the Ministry of Education of Vietnam, VnExpress of Vietnam:http://vnexpress.net/infographics/giao-duc/du-hoc-sinh-viet-nam-dang-hoc-tap-tai-nhung-nuoc-nao3493240.html)

There are 5,519 students among the 130,000 students adopting the educational appropriation of Vietnamese government. Students pursuing doctorate and bachelor's degree receive appropriation with the number of 2501 and 2375 respectively. It shows the Vietnamese government implements two schemes at the same time to solve the problem that the country requires talents at present and establish the long-term plan of national human resources.

Although Japan has the most Vietnamese students, America becomes the pursuit of Vietnamese students to study. The statistics of Vietnam embassy in America show in 2015, Vietnam sent the most overseas students of about 19,000 to America than the other countries in Southeast Asia and ranked ninth in the ranking list of study-abroad quantity statistics of America. In 2017, the number of Vietnamese students reaches 28,000 ranking fifth in America. [4] The data statistics with rapid growth is unimaginable, reflecting the spirit of overseas Vietnamese students in making forward progress and attending school.

In recent years, Vietnamese students are willing to study in China. China has the most population and becomes the second great power of market economy in the world. The government of China pays special attention to the educational reform in colleges: achieve high quality, large scale and integrate in the world education. Just as the celebrated dictum said by Yan $\mathrm{Zi}$ from Chunqiu period of China that "Whoever understands the times is a great man", an increasing number of Vietnamese students studies in 
China in recent years, indicating the Vietnamese government understands the times and the students have aspiration.

\section{FACTORS INFLUENCING THE AMBITION OF OVERSEAS VIETNAMESE STUDENTS AND DIFFICULTIES IN STUDYING}

\section{ABROAD}

Ruan Yuxiong, the deputy director in charge of foreign international relations in the Ministry of Education in Vietnam observes the reason why the number of overseas Vietnamese student increases is that the Vietnamese government mobilizes Vietnamese students to study abroad. After all, they are human resources of Vietnam. Teachers in foreign countries often speak highly of overseas Vietnamese students because they are clever and quick-witted, bear hardships and stand hard work. The deputy director thinks Vietnamese students have gifts in science and engineering but they have to choose other ways because of the poor learning environment in Vietnam. Zhan Yuanzhen, a professor in Ecole Polytechnique who can be called as "the bridge of studying abroad" shows it is early to conclude. But according to the school records and research achievements of overseas Vietnamese students, they will become the key high quality human resource team for the Vietnamese government to realize globalization of Vietnam.

\section{A. Influence of Study-Abroad Educational Policies of Vietnamese Government}

The Ministry of Education of Vietnam opens channels of study-abroad information to support, encourage and mobilize students to study abroad through adopting funds from educational appropriation or self-funded way. Students who are willing to study abroad can adopt information of two channels: the first is internet and the second is intermediate organizations for consulting about studying abroad. Meanwhile, the Ministry of Education extensively organizes some free and short-term language training class and establishes platforms related to consulting about studying abroad for students before studying abroad. The training class is organized by the Ministry of Education or education and training centers. The study-abroad policies of the Vietnamese government have great influence on students who have intention to study abroad and let them make choice in studying abroad boldly.

Students adopting funds of educational appropriation from the state government write reports about their learning situation and living environment and propose their difficulties and countermeasures when studying abroad. Vietnamese government advocates establishing the Vietnamese group, in order to provide a platform for overseas Vietnamese students to help and communicate with each other and unite as one. Meanwhile, it can consolidate the patriotic ideal of overseas Vietnamese students and improve their spirit of making contributions to the country. Ten percent of Vietnamese students return home to work. Most students who adopt the funds of educational appropriation from the national government return home to work. Ninety percent of students who go to study abroad at their own expense don't choose to return home. For the former, some think they will be put in an important position by the national government and have promising career and good treatment while others think it cannot meet their requirements in working conditions to return home to work because of the low living standard and poor treatment. Few self-funded overseas students choose to return home to work. The Vietnamese government cannot ignore this problem but consider study-abroad policies and the treatment of graduates returning home to work. At present, it is extremely urgent for Vietnamese government to think how to treat overseas students and how to solve the problem of the brain drain. The current treatment policy fails to attract them. Selffunded overseas students are not interested in the treatment in Vietnam and don't care about the study-abroad policy of the government. The investigation report of the Foreign Training Bureau of Vietnam indicates 70 percent of selffunded overseas students are willing to work in the foreign country or look for business in other developed countries. The increasingly serious brain drain makes the force for Vietnamese government to construct a national undertaking of globalization weaker.

\section{B. Influence of Brain Drain}

Although Vietnamese government has racked wits about the vital interests of overseas students and has formulated many study-abroad policies to promote vigorously, Vietnam has a short history in formulating study-abroad policies and the national educational appropriation is limited, meanwhile, the bureaucratic corruption directly influences the development policy of social economy. Study-abroad policy is not an exception. At present, a large number of Vietnamese students study abroad and they are talents in the development of Vietnam. However, Vietnamese government fails to solve the problem of brain drain. The annual data statistics of the Ministry of Education reflects lots of students are reluctant to return home to work. It is the immeasurable loss of Vietnamese government in constructing the country of freedom, justice, equality and rule of law.

Vietnamese government has requirements for a large number of high quality talents in constructing the country of market economy. The brain drain has become the problem restricting the development of Vietnam. Some developed countries formulate policies to attract talents through providing good living condition, working environment and perfect treatment policy. For example, Australia provides green card for high level Vietnamese. Singapore allows overseas Vietnamese students to stay if they are employed by companies in Singapore. China and other European countries also have good treatment for overseas students. America attracts high quality overseas students through the superior conditions.

\section{Influence of Society and Family}

In the thousands of years of tradition, Vietnamese value intellectuals. All historic changes cannot change the spirit of Vietnamese students to attend school. The knowledge and ambition of the ancients in the past makes them have a niche in history. Achievements and career of predecessors directly influence the thoughts of students. They are encouraged to study abroad and establish a high quality scientific research 
method and train knowledge capacity and scientific research ability and modern work style that can keep abreast with the professional work style in developed countries.

Another factor that influences the aspiration of students to study abroad is family relationship. The open economic market in Vietnam brings increasingly affluent economic conditions for Vietnamese. More and more well-off families appear in Vietnam. Rich parents hope children can enjoy the sound educational environment in developed countries through studying abroad. According to actual statistics, many parents send children to study abroad since they are in junior or senior high school because they think it is better for children to learn foreign languages in a younger age. Students are expected to rapidly adapt to living conditions in foreign countries, learn foreign language skills and enjoy advanced learning environment and teaching methods. Besides, they think the children will smoothly accept the difficult and high level training mode in foreign countries. However, family and social psychologists in Vietnam think it is appropriate to send students in junior and senior high school to study abroad because they can grow normally when parents accompany them. Young students will go astray easily without the discipline of parents. Moreover, few self-funded students are willing to return home to work. Vietnam must reform education to construct the country of globalization, but it is necessary to keep the traditional virtues and culture of families in East Asia.

Except for domestic and foreign study-abroad policies, family and social problems, another reason that influences the aspiration of students to study abroad is cultural difference and individualism. The worship of individualism and the pursuit of personal interests will directly influence overseas Vietnamese students.

\section{AdJUST STUdy-ABRoAd Policies OF VIETNAMESE} GOVERNMENT, ENCOURAGE STUDENTS TO STUDY ABROAD AND MOBILIZE THEM TO RETURN HOME TO WORK

At present, Vietnamese government attaches importance to the research on study-abroad policies. In order to provide human resources of international standard for the globalization requirements of Vietnam, the national government has been trying to formulate and improve studyabroad policies.

According to the statistics of the State Statistics Bureau of Vietnam, the growth rate of the five-year plan on GDP namely the Five-year Plan of Social and Economic Development from 2011 to 2015 slows down. The growth rate of 2016 reaches 6.21 percent, failing to reach 6.68 percent in 2015. The expected growth rate in the period from 2016 to 2020 in the five-year plan of social and economic development is 6.7 percent. [6] Unstable global financial market and RMB devaluation and the decrease of economic index number in China influence economic development of countries in the world. In Vietnam, prices have drastic fluctuation and the crude oil price falls, leading to the balance of payments disequilibrium of government allocations, backward economic development and decrease of average revenue. Vietnamese government faces great change of domestic economic system from processing and assembling to manufacturing, from production to creation. The capital investment in plant and equipment and production transforms into human resources investment and talent service for independent development.

Social development depends on talents to take the lead. In order to construct a civilized country comparable to developed country, it is necessary to learn social operation and management styles of western countries and understand their macroscopic and microscopic educational training strategies. Besides, it requires overseas Vietnamese talents who experience similar social learning and researches and live and work in advanced countries to take the lead.

Study-abroad treatment policies directly influence students who study abroad or return home to work. A reasonable policy should guarantee the vital interests of overseas students: in the first period of "preparing for studying abroad", students are provided with study-abroad information especially the detailed information about living conditions, specialties and research directions in foreign countries. In the second period of "studying abroad", students are influenced by many reasons like language barrier, living environment and cultural difference. At this time, students should be mobilized and encouraged spiritually. In the third period of "graduation", students who return home to work should be concerned properly. The government provides good working conditions and treatments for graduates and lets them feel it is the best choice to return home to work.

Policies in the three periods of studying abroad are of vital importance. At present, the brain drain is serious in Vietnam. Most graduates are reluctant to return home. Vietnamese government faces an extremely urgent problem: how to treat overseas Vietnamese students and how to make them return home willingly through policies.

From the early years after liberation of North Vietnam in 1945 to the unification of Vietnam in 1975, Vietnamese government sent staff of government departments, postgraduates, students and technicians to study abroad. At that time, Vietnamese had aspiration to construct motherland. They are willing to study abroad in order to make contributions for motherland and achieve the revolutionary ideal. With the coming of the 21 st century, the new era brings Vietnamese a stable society and negative influences on people, individualism and the pursuit of personal interests, leading to the serious brain drain. The superior treatment of foreign countries attracts overseas students to pursue personal interests. Most overseas students consider personal interests instead of the future of motherland. Vietnam is in urgent need of talents who value the construction of motherland. The spirit of making contributions to the country is more important than academic record. Vietnam has suffered from innumerous disasters during the thousands of years. Vietnamese cherish the memory of chairman Ho Chi Minh and remember the spirit of him to make contributions to motherland. Today's Vietnamese students should learn from him. He sets a good example of studying hard, abandons personal interests and individualism, studies 
abroad to learn quintessence of foreign countries, returning home to carry out earth-shaking career, "make Vietnam independent and liberate Vietnam". Chairman Ho Chi Minh makes contributions to Vietnamese revolution and sacrifices for the motherland. His spirit deserves Vietnamese from generation to generation to learn. Vietnamese government requires the team with spirit of Ho Chi Minh. Therefore, experts who formulate policies in Vietnam should regard overseas Vietnamese as the backbone in development of the country.

In conclusion, reasonable study-abroad policies must be formulated to meet the aspiration of overseas students to return home to work and promote the mechanism of attracting talents. It is most important to solve the studyabroad problem "the conflicts between personal interests, individualism and national interests". The vital interests of overseas students must be integrated in national interests. At the meantime, Vietnamese government should value the training of moral education for talents who have the ideal of constructing motherland, dedicate to the national interests and make contributions to motherland, in order to construct a developed Vietnam. Moreover, Vietnamese government should ensure overseas Vietnamese students enjoy treatment policies, the implementation of policies and the quality of talents. Measures are taken to improve the treatment of talents and provide good living conditions and working environment for them. Sound treatment policies can attract talents and let them make contributions to motherland whole-heartedly.

\section{CONCLUSION}

According to the current situation of global economy, talents from many countries compete for a good position equally. Competent people must have "internationalized skills" to keep pace with talents worldwide and create career. Internationalized labor market has extremely high demand. The fastest and most simple way and the most direct way is to study abroad. A country will have developed construction, make progress and have sustainable power if the government of it can make policies to encourage people to study abroad and can make policy of sending college students abroad for academic studies. Study-abroad policy is not a easy problem for a government. In order to solve the problem roundly and let overseas students have the ambition of returning home to work, research departments of the government in formulating policies should have macroscopic and microscopic analytic ability and objective perspective to distinguish internal influence factors and external ones.

To sum up, in order to improve the number of talents that return home to contribute after graduation and avoid the loss of talent resources caused by the brain drain, educational departments of the government should take the following measures:

- Study-abroad policies and popularization: disclose information on official website of education (studyabroad information disclosure on official website of foreign training bureau of the Ministry of Education in Vietnam); coordinate with domestic universities to popularize information related to study abroad program.

- Intermediate organizations of consulting on the study abroad: establish study-abroad consultative department nationwide and normalize its power, functions, tasks and working range. They must have corporate capacity under the management of government sectors.

- Study-abroad procedures: simplify the study-abroad procedures and ensure its authenticity, like the application of scholarship, visa letter, graduation certificate and certificate of physical examination.

- When allocating funds in education, the government should disclose regulations and procedures in application of government scholarship, providing overseas students with contact information of departments in study-abroad management, consultation and assistance.

- The educational development of a country closely relates to the advanced training and learning style of foreign language. The training of foreign language makes preparations for students in studying abroad and lets them adapt to teaching and learning styles as well as life styles of foreign countries.

- Improve the system for talent treatment: improve the existing work environment of Vietnam and the employment system of units, departments and enterprises, in order to provide good working conditions and treatment for students who return home after graduation.

Overseas students and domestic students are free and independent to choose whether to work in the motherland. Policies will take effect roundly if education departments of Vietnam and person in charge of educational policies formulate appropriate and effective study-abroad policies through experiencing overseas students' aspirations. The priority is how to adopt and use. Globalization brings education in Vietnam a lot of interests. First, globalization makes the government of Vietnam know more about education around the world and evaluate the position of education in Vietnam and the education and training level. The closed society in Vietnam makes Vietnamese like a person of narrow view. The absorption of advanced educational experience in developed countries not only provides a good example for education in Vietnam but also creates a development impetus for the reform of education in Vietnam. It thoroughly breaks the outdated educational methods in Vietnam. Learning the advanced educational experience in advanced countries will become an indispensable enlightenment for the educational reform of the government in Vietnam. Overseas students are an important factor for the government in Vietnam to construct a developed country and the "bridge" between the national government and countries around the world. 


\section{REFERENCES}

[1] http://nld.com.vn/giao-duc-khoa-hoc/60000-du-hoc-sinh-nguon-nhanluc-tuong-lai-243931.htm

[2] https://en.wikipedia.org/wiki/Education_in_Vietnam

[3] http://www.iie.org/Research-and-Publications/Open-Doors

[4] https://vn.usembassy.gov/vi/pr151116/

[5] http://nld.com.vn/giao-duc-khoa-hoc/60000-du-hoc-sinh-nguon-nhanluc-tuong-lai-243931.htm

[6] https://www.gso.gov.vn/default.aspx?tabid=621\&ItemID=15507, https://www.gso.gov.vn/default.aspx? tabid=382\&idmid=2\&ItemID= 16171

[7] Jens Jakobsen,Kjeld Rasmussen,Stephen Leisz,Rikke Folving,Nguyen Vinh Quang. The effects of land tenure policy on rural livelihoods and food sufficiency in the upland village of Que, North Central Vietnam[J]. Agricultural Systems . $2006: 9(2): 69-73$

[8] Tang Weibing;Fu Yuanhai;Wang Zhanxiang;technology innovation,techolog introduction and transformation of economic growth pattern[J].Economic Research Journal.2014(07):237-242

[9] https://en.wikipedia.org/wiki/Ho_Chi_Minh

[10] Ruan Chenggong. Problems in Quality of Human Resources in Vietnam [J], Modern Economic Information, 2014(21): 115-116

[11] Huang Du Haiyan. Research on Current Situation of Cultural Tourism Brands in Vietnam and Development Measures [D], Central South University, 2014: 13-16

[12] Liu Hongxia, Fang Jiaxi. Research on Motivation of College Students in Studying abroad [J], China Youth Study, 2011

[13] Mao Li, America: Successful Talent Introduction Policy [J], International Talent, 2009 (03): 10-11

[14] Jiang Ning. Policies on Study-abroad Education of American Universities and Its Influence [J], Shanghai Research in Higher Education, 1998(10): 34-37

[15] Han Ye. Introduction to Current Situation of the World's Studyabroad Education [J], Comparative Education Research, 1997(02): 49-50

[16] Shen Ronghua. Development Tendency of Chinese Talent Policy in the Future [J], Chinese Talents, 2013(17): 26-28

[17] Ruan Qingxiong. "Combination of Talent Training and Social Needs": Exploration and Analysis on Reform of Higher Education in Vietnam [J], Survey of Education, 2013(11): 35-39 